\title{
SYMPOSIUM ON NEW APPROACHES TO THE \\ RHEOLOGICAL CHARACTERIZATION OF BIOLOGICAL MATERIALS
}

The following papers comprise 2 of the 3 invited lectures and 4 of 6 other communications given at the symposium which are available for publication at this time. Abstracts of all the contributions will be found in Biorheology 12, 81, 1975:

\section{INVITED PAPERS}

1. Microscopic Techniques for the in situ Characterization of Concentration of Tissue Components and Penetrating Molecules.

Siegried Witte, Karlsruhe, West Germany.

2. Some Model Experiments in Hemodynamics vs Microrheological Techniques.

H. L. Goldsmith and S. G. Mason, Montreal, Canada.

\section{Symposium Contributions}

3. Rheo-Optical Studies of Blood Cells.

M. M. Frojmovic, Montreal, Canada.

4. Measurement of Blood Flow In vivo by Laser Doppler Anemometry through a Microscope.

S. Einvav, H. J. Berman, R. L. Ruhro, P. R. DiGiovanni, J. D. Fridman and S. Fine, Boston, U.S.A.

5. Measurement of Velocity Profiles of Red Blood Cells in the Microcirculation by Laser Doppler Anemometry (LDA).

S. Einav, H. J. Berman, R. L. Ruhro, P. R. DiGiovanni, S. Fine and J. D. Fridman, Boston, U.S.A.

6. Fast Reacting Viscometer for Low Wall Shear Stress Measurements.

B. Obrecht, A. Lyazid, Ch. Kopp and R. Feidt, Strasbourg, France. 